\title{
Yield Attributes and Yield of Summer Pearl Millet as Influenced by Cultivars and Integrated Nutrient Management
}

\author{
G. Divya", K.P. Vani, P. Surendra Babu and K.B. Suneetha Devi \\ Department of Agronomy, College of Agriculture, Prof. Jayashankar Telangana State \\ Agricultural University, Rajendranagar, Hyderabad-030, Telangana, India \\ *Corresponding author
}

\section{A B S T R A C T}

\section{Keywords}

Yield attributes,

Pearl millet,

Nutrient.

Article Info

Accepted:

14 September 2017

Available Online:

10 October 2017
A field experiment was conducted during summer season, 2017 on sandy loam soil of college Farm, College of Agriculture, Professor Jayashankar Telangana State Agricultural University, Rajendranagar, Hyderabad. The experiment was laid out in Factorial Randomized Block design with 9 treatments and each treatment replicated three times. PHB-3 recorded significantly higher yield attributes, grain yield and stover yield compared to ICMV-221 and Dhanashakti. Among integrated nutrient management practices, 75\% RDF + Biofertilizers @ $5 \mathrm{~kg} \mathrm{ha}^{-1}$ incubated with V.C @ 500 $\mathrm{kg} \mathrm{ha}^{-1}$ recorded significantly higher yield attributes, grain yield and stover yield over $75 \% \mathrm{RDF}+25 \% \mathrm{~N}$ through vermicompost and $100 \% \mathrm{RDF}$.

\section{Introduction}

Pearl millet (Pennisetum glaucum) is grown in arid and semi-arid regions of India for both grain and fodder. In India it is the fifth most important cereal grain crop next to rice, wheat, maize and sorghum. It is an imperative drought escaping cereal crop. India is the largest producer of pearl millet in the world occupying 7.32 Million hectares with annual production of 9.18 Million tonnes and average productivity of $1255 \mathrm{~kg} \mathrm{ha}^{-1}$ (Directorate of Economics and Statistics, 2016). The Pearl millet growing countries are India, China, Nigeria, Pakistan, Sudan, Egypt, Arabia, and Russia. Pearl millet grain is more nutritious and the grain contains $11-19 \%$ protein, 60$78 \%$ carbohydrates and $3.0-4.6 \%$ fat and also has good amount of phosphorous and iron (Reddy et al., 2016). Though various breeding efforts in pearl millet have produced agronomical elite cultivars-both hybrids and varieties with high yielding potential, their adoption has been low in arid areas. Selection of a proper hybrid/variety is an important consideration that affects pearl millet production and productivity levels. Cultivars with different make up respond differently to various climatic conditions. Hybrids performs well with irrigation facilities or with good and evenly distributed rainfall, whereas varieties are well adapted to harsh growing areas and usually perform better than modern cultivars (Yadav et al., 2003). Main reason for low 
productivity of this crop is water and nutritional stresses. One of the easiest ways for boosting productivity of pearl millet is the use of balanced fertilizers to the undernourished crop. Integrated use of chemical fertilizers with organic manures has been found to be quite promising in maintaining high productivity and providing greater stability to crop production (Patidar and Mali, 2004). Keeping in view of the importance the study was aimed to investigate the effect of cultivars and integrated nutrient management on yield, yield attributes and economics of summer pearl millet.

\section{Materials and Methods}

Field experiment was conducted in sandy loamy soil at College Farm, College of Agriculture, Professor Jayashankar Telangana State Agricultural University, Rajendranagar, Hyderabad. The $\mathrm{pH}$ of the experimental site was 7.7 , organic carbon was $0.65 \%$, available nitrogen, phosphorus and potassium were 180 $\mathrm{kg}$ ha-1, $85 \mathrm{~kg} \mathrm{ha}{ }^{-1}$ and $360 \mathrm{~kg} \mathrm{ha}$ respectively. The treatments consisted of three cultivars namely, ICMV-221 $\left(\mathrm{C}_{1}\right)$, Dhanashakti $\left(\mathrm{C}_{2}\right)$ and PHB-3 $\left(\mathrm{C}_{3}\right)$ as first factor and three integrated nutrient management practices i.e., $100 \%$ RDF $\left(\mathrm{F}_{1}\right)$, $75 \% \mathrm{RDF}+25 \% \mathrm{~N}$ through vermicompost $\left(\mathrm{F}_{2}\right)$ and $75 \% \mathrm{RDF}+$ Biofertilizers @ $5 \mathrm{~kg}$ $\mathrm{ha}^{-1}$ incubated with V.C @ $500 \mathrm{~kg} \mathrm{ha}^{-1}\left(\mathrm{~F}_{3}\right)$ as second factor comprising nine treatment combination, laid out in randomized block design with factorial concept, replicated thrice. Pearl millet was sown on $16^{\text {th }}$ January, 2017 and harvested on $20^{\text {th }}$ April. During the growing season, the mean weekly maximum, minimum temperature, relative humidity, sunshine hour day $^{-1}$ and evaporation were $34.7^{\circ} \mathrm{C}, 16.8^{\circ} \mathrm{C}, 76.1 \%, 26.2 \%, 8.7 \mathrm{hrs} \mathrm{dy}^{-1}$ and $6 \mathrm{~mm}$. Pearl millet was planted at a spacing of $45 \mathrm{~cm} \times 15 \mathrm{~cm}$ using seed rate of 4 $\mathrm{kg} \mathrm{ha}^{-1}$. The N, P and $\mathrm{K}$ were applied through urea, vermicompost, SSP and MOP as per the treatments. Entire dose of phosphate and potash and half dose of $\mathrm{N}$ were incorporated into the soil basally at the time of final land preparation. The remaining half $\mathrm{N}$ was applied as split application at 30 DAS. Azospirillum and PSB each @ 5kg ha ${ }^{-1}$ were incubated with vermicompost @ $500 \mathrm{~kg} \mathrm{ha}^{-1}$ at room temperature for 15 days and incorporated in the soil thoroughly with the help of spades before sowing.

At harvesting, 5 plants were sampled from the net plot from the plot-border of each plot to observe the yield attributes like girth of ear head, ear head length, no. of grains per ear head, grain weight per ear head and test weight. To determine grain yield, ear heads from the net plot were harvested and sun dried. Threshing was done by beating the ear heads with sticks. The separated grains were cleaned, dried in sun to bring down the moisture content to $12 \%$.

To determine stover yield, stalks were cut at ground level and weighed after sun drying. The data were subjected to analysis of variance procedures as outlined for randomized block design factorial concept (Gomez and Gomez, 1984). Statistically significance was tested by F-value at $0.05 \%$ level of probability and critical difference was worked out where ever the effect were significant.

\section{Results and Discussion}

\section{Yield attributes}

Among the three cultivars PHB-3 registered significantly higher yield attributes viz., no. of effective tillers $\mathrm{m}^{-2}$, girth of ear head, ear head length, no. of grains per ear head, grain weight per ear head and test weight compared to ICMV-221 and Dhanashakti (Table 1). The difference in number of effective tillers of these cultivars could be attributed to the higher tillering ability and conversion of total tillers into reproductive tillers. 
Table.1 Yield attributes and yield as influenced by cultivars and integrated nutrient management

\begin{tabular}{|c|c|c|c|c|c|c|c|c|}
\hline Treatments & $\begin{array}{l}\text { No. of } \\
\text { effectiv } \\
\text { e tillers } \\
\mathrm{m}^{-2}\end{array}$ & $\begin{array}{l}\text { Girth } \\
\text { of ear } \\
\text { head } \\
(\mathrm{cm})\end{array}$ & $\begin{array}{l}\text { Ear } \\
\text { head } \\
\text { length } \\
(\mathrm{cm})\end{array}$ & $\begin{array}{l}\text { No. of } \\
\text { grains } \\
\text { per ear } \\
\text { head }\end{array}$ & $\begin{array}{c}\text { Grain } \\
\text { weight } \\
\text { per ear } \\
\text { head }(\mathrm{g})\end{array}$ & $\begin{array}{c}\text { Test } \\
\text { weight } \\
(\mathrm{g})\end{array}$ & $\begin{array}{l}\text { Grain yield } \\
\left(\mathrm{kg} \mathrm{ha}^{-1}\right)\end{array}$ & $\begin{array}{l}\text { Stover yield } \\
\quad\left(\mathrm{kg} \mathrm{ha}^{-1}\right)\end{array}$ \\
\hline \multicolumn{9}{|l|}{ Cultivars } \\
\hline $\mathrm{C}_{1}:$ ICMV-221 & 12.4 & 10.3 & 21.4 & 2075 & 19.6 & 9.64 & 2389 & 4607 \\
\hline $\mathrm{C}_{2}$ : Dhanashakti & 13.7 & 10.9 & 23.1 & 2205 & 21.7 & 10.25 & 2605 & 4910 \\
\hline $\mathrm{C}_{3}:$ PHB-3 & 15.2 & 11.6 & 26.2 & 2423 & 24.0 & 11.12 & 3239 & 5458 \\
\hline $\mathrm{SEm} \pm$ & 0.30 & 0.19 & 0.48 & 42 & 0.7 & 0.18 & 58.3 & 90.0 \\
\hline $\mathrm{CD}(\mathrm{P}=0.05)$ & 0.90 & 0.58 & 1.4 & 126 & 2.0 & 0.55 & 174.8 & 269.7 \\
\hline \multicolumn{9}{|l|}{ Integrated nutrient management } \\
\hline $\mathrm{F}_{1}: 100 \% \mathrm{RDF}$ & 12.9 & 10.6 & 22.6 & 2154 & 20.5 & 9.98 & 2572 & 4803 \\
\hline $\mathrm{F}_{2}: 75 \% \mathrm{RDF}+25 \% \mathrm{~N}$ through V.C & 13.6 & 10.8 & 23.2 & 2210 & 21.3 & 10.24 & 2693 & 4932 \\
\hline $\begin{array}{l}\mathrm{F}_{3}: 75 \% \mathrm{RDF}+\text { Biofertilizers } \\
\text { incubated with V.C @ } 500 \mathrm{~kg} \mathrm{ha}^{-1}\end{array}$ & 14.7 & 11.5 & 24.8 & 2339 & 23.4 & 10.80 & 3001 & 5240 \\
\hline $\mathrm{SEm} \pm$ & 0.30 & 0.19 & 0.48 & 42 & 0.7 & 0.18 & 58.3 & 90.0 \\
\hline $\mathrm{CD}(\mathrm{P}=0.05)$ & 0.90 & 0.58 & 1.4 & 126 & 2.0 & 0.55 & 174.8 & 269.7 \\
\hline \multicolumn{9}{|l|}{ Interaction } \\
\hline $\mathrm{SEm} \pm$ & 0.52 & 0.33 & 0.83 & 72.7 & 1.18 & 0.32 & 100.9 & 155.8 \\
\hline $\mathrm{CD}(\mathrm{P}=0.05)$ & NS & NS & NS & NS & NS & N.S & NS & NS \\
\hline
\end{tabular}

$\mathrm{RDF}=80: 40: 30 \mathrm{~kg} \mathrm{ha}^{-1} \mathrm{~N}: \mathrm{P}_{2} \mathrm{O}_{5}: \mathrm{K}_{2} \mathrm{O}, 25 \% \mathrm{~N}$ through V.C $=1.7$ tonnes of vermicompost, Biofertilizers = $($ Azospirillum $+\mathrm{PSB})$ each @ $5 \mathrm{~kg} \mathrm{ha}{ }^{-1}$ 
Among the cultivars better partitioning of photosynthates from source to sink might have resulted in higher length of ear head. Test weight is mainly controlled by genetic makeup of the cultivars. Higher test weight of PHB-3 might be attributed to increase in transformation of assimilates in grain and subsequent development of more bold seeds. These results also substantiate the findings of Munirathnam and Gautam (2002) and Kumar et al., (2004). Among the integrated nutrient management 75\% RDF + Biofertilizers @5 $\mathrm{kg} \mathrm{ha}^{-1}$ incubated with V.C @ $500 \mathrm{~kg} \mathrm{ha}^{-1}\left(\mathrm{~F}_{3}\right)$ recorded higher yield attributes over other treatments $F_{1}$ and $F_{2}$ (Table 1). The increase in yield attributes may be due to the fact that INM application of fertilizer make more availability of nutrients which is provide to a higher availability of nutrient to the plant, while vermicompost improves the soilphysical properties, hydraulic conductivity of the soil and also the availability of NPK, which promoted plant growth and development and resulting in increasing yield attributes of pearl millet. Use of bio-fertilizer (Azospirillum + PSB) led to higher availability of $\mathrm{N}$ and $\mathrm{P}$ as well as promoted the root growth, which promoted yield attributes characters. Corroborative results have also been reported by Lakum et al., (2011) and Patel et al., (2016), Bana et al., (2012).

\section{Grain yield}

It was revealed from the results (Table 1) that the highest grain yield was produced with PHB-3 compared to ICMV-221 and Dhanashakti. It is well known fact that grain yield is the outcome of yield attributing characters, which also showed differentiation with different cultivars. These results corroborates with the findings of Satyajeet et al., (2007). 75\% RDF + Biofertilizers @ $5 \mathrm{~kg}$ ha $^{-1}$ incubated with V.C @ $500 \mathrm{~kg} \mathrm{ha}^{-1}\left(\mathrm{~F}_{3}\right)$ produced maximum grain yield of pearl millet and was significantly superior over rest of the treatments. Increase of grain yield might also be due to the increased photosynthetic activity which resulted in higher accumulation of photosynthates and translocation to sink due to better source and sink channel which resulted in higher grain yield. These observations corroborate with those made by Patil and shete (2008).

\section{Stover yield}

Higher stover yield was observed with PHB-3 which was significantly superior over ICMV221 and Dhanashakti (Table 1). The more plant height, higher tiller number and dry matter accumulation recorded in the cultivar PHB-3 may have contributed for its higher stover yield over other two cultivars. The results were in accordance with Yadav and Kumar (2013). 75\% R DF + Biofertilizers@ $5 \mathrm{~kg} \mathrm{ha}^{-1}$ incubated with V.C @ $500 \mathrm{~kg} \mathrm{ha}^{-1}$ $\left(\mathrm{F}_{3}\right)$ recorded higher stover yield compared to $F_{1}$ and $F_{2}$. An increase in uptake of plant nutrients empowered the plant to manufacture more quantity of photosynthates resulting in more stover yield. Similar results were reported by Thumar et al., (2016).

\section{References}

Bana, R.S., Gautam, R.C and Rana, K.S. 2012. Effect of different organic sources on productivity and quality of pearl millet (Pennisetum glaucum) and their residual effect on wheat (Triticum aestivum). Annals of Agricultural Research. 33(3):126-130.

Directorate of economics and statistics.2016. Agricultural Statistics at a glance.pp101.

Gomez, K.A., and Gomez, A.A.1984. Statistical procedure for agriculture research. John Wiley and Sons Publishers, New York.357-423.

Kumar, S., Kadian, V. S and Singh. R. C. 
2004. Response of pearl millet (Pennisetum glaucum L.) hybrids to row spacing and nitrogen application. Annals of Agricultural Research. 25(1): 68-70.

Lakum, Y.C., Patel, S.H and Mehta, P.V.2011. Reducing fertilizer requirement with the use of biofertilizers in summer pearl millet [Pennisetum glaucum (L.)]. An Asian Journal of Soil Science. 6(1): 5 0-53.

Munirathnam, P., and Gautam, R.C.2002.Response of promising pearl millet (Pennisetum glaucum L.) cultivars to levels and time of nitrogen application under rainfed conditions. Indian Journal of Agronomy 47(1): 7780

Patel, V.R., Patel, B.M., Patel, J.M and Patel, P.M.2016. Integrated nitrogen management in summer pearl millet [Pennisetum glaucum (L) R.Br. Emend Stuntz].Gujarat Agricultural University Research Journal 41(2): 61-64.

Patidar, Mand Mali, A.L. 2004. Effect of farm-yard manure, fertilizer levels and biofertilizers on growth, yield and quality of sorghum (Sorghum bicolor). Indian Journal of Agronomy 19(1): 8386.

Patil, H.M., and Shete, B.T. 2008. Integrated nutrient management in pigeonpea- pearlmillet intercropping system under dryland conditions. Journal of Maharashtra Agricultural University. 33(1): 119-120.

Reddy, S.B.P., Naga madhuri, K.V., Keerthi Venkaiah and Prathima, T. 2016. Effect of nitrogen and potassium on yield and quality of pearl millet (Pennisetum glaucum L.) International Journal of Agriculture Innovations and Research. 4(4): 678-681

Satyajeet, Nanwal, R. K., Yadav, V. K and Kumar, P. 2007. Effect of integrated nutrient management on productivity of pearl millet (Pennisetum glaucum L.) and its residual effect on succeeding mustard (Brassica juncea). Haryana Agricultural University Journal of Research.37: 15-18.

Thumar C.M., Dudhat M.S., Chaudhari N.N, Hadiya N.J and Ahir N.B.2016. Growth, yield attributes, yield and economics of summer pearl millet (Pennisetum glaucum L.) as influenced by integrated nutrient management. International Journal of Agriculture Sciences.8 (59): 3344-3346.

Yadav, A.K., and Kumar, A.2013. Comparitive performance of pearlmillet genotypes in terms of yield and quality under different environment. Forage Research. 39(1):31-35.

\section{How to cite this article:}

Divya, G., K.P. Vani, P. Surendra Babu and Suneetha Devi, K.B. 2017. Yield Attributes and Yield of Summer Pearl Millet as Influenced by Cultivars and Integrated Nutrient Management. Int.J.Curr.Microbiol.App.Sci. 6(10): 1491-1495. doi: https://doi.org/10.20546/ijcmas.2017.610.177 